\title{
Wish list: which biomarker studies in HAM/TSP should be funded by the God of all trial funds?
}

\author{
Yoshihisa Yamano \\ From 16th International Conference on Human Retroviruses: HTLV and Related Viruses \\ Montreal, Canada. 26-30 June 2013
}

Since the discovery of HAM/TSP, little progress has been made on developing treatments. As HAM/TSP usually progress slowly, it can take a long time to evaluate disease activity and decide on a course of treatment. Therefore, there is a dire need for biomarkers capable of predicting the rate of disease progression and "surrogate end-points" that enable new treatments to be assessed more rapidly and with greater accuracy in clinical trials. However, in order to validate surrogate end-points, it is necessary to conduct large-scale, randomized clinical trials - a very difficult feat for such a rare disease. Here we present a recent study on candidate prognostic biomarkers for HAM/TSP and discuss future research directions.

Submit your next manuscript to BioMed Central and take full advantage of:

- Convenient online submission

- Thorough peer review

- No space constraints or color figure charges

- Immediate publication on acceptance

- Inclusion in PubMed, CAS, Scopus and Google Scholar

- Research which is freely available for redistribution 